\title{
Government and NGOs Performance with Respect to Women Empowerment in Nigeria
}

\author{
DIBIE, Robert | OKERE, Justina Sam
}

\section{Abstract}

This his study investigates the performance of the Government of Nigeria and NGOs in the empowerment of women in the country. It examines the following research questions: is there a positive relationship between government policies and its inability to enforce domestic abuse crime, sexual harassment, and male hostile domination? Are NGOs women empowerment and women liberation programs more effective than those of the government of Nigeria? To address these questions, the study uses data on NGOs that provides major capacity building projects (i.e., women education, legal rights and entrepreneurship projects) and government programs for combating discrimination against women in the six geo-political zones of Nigeria. This study uses both qualitative and quantitative research methods to examine the role of government and NGOs in the empowerment of women in Nigeria On one hand, results point toward a negative relationship between government and women empowerment policies. On the other hand, result shows a positive correlation between NGOs and women empowerment in Nigeria. Further cultural, religious, social and economic factors as well as the lack of effective implementation of gender policies continue to militate against the integration of women in the country. Our research included a survey of some 2,250 women that have benefited from NGOs empowerment program. One striking discovery is that Nigerian women have benefited more from NGOs empowerment programs than those provided by the government. Women who benefited from NGOs empowerment programs have progressed from being victims of domestic abuse unemployment to entry-level jobs and subsequently to middle management. About 15 percent of them have move from middle management to senior management. The results of this study 
Government and NGOs Performance with Respect to Women Empowerment in Nigeria 93

have implications for NGOs management in the context of women projects management and governments' political willingness to collaborate with NGOs in addressing women's empowerment and capacity-building issues in Nigeria.

\section{Keywords: NGOs, Capacity Building, Government Performance, Women Empowerment}

\section{Introduction}

The history of women in Nigeria presents an account of tremendous abuse, discrimination and diversity in the country. Since the beginning of the past five decades women's role in the country could be described as neither one of total victimization or deprivation, nor of complete equality with their male counterpart. Although, the 1999 Constitution of Nigeria prohibits discrimination on the basis of gender, the customary and religious laws continue to restrict women's rights (The Constitution of the Federal Republic of Nigeria, 1999). According to Dibie (2014) the combination of federal system of government, and a tripartite system of religious laws, civil and customary laws make it very difficult to harmonize legislation and remove discriminatory measure against women in Nigeria.

The women's movement for sexual equality in Nigeria began in the 1950s. It developed out of the larger social movement to gain independence from the British colonial administration (Okojie 1995; Kolawole 1988; Sha 2007; Ogidefa (2008). According to Angya (2005) women's attempts to liberate themselves from the constraints of female role stereotypes have further induced a growing number of men to free themselves from male role stereotype.

The women's movement has failed, however to achieve one of its primary objectives of eradicating discrimination through the Federal Government of Nigeria enacting a bending public policy to that effect. Another factor contributing to the rebirth of feminism in the country was the 2014 Boko Haram adoption of 250 girls from the northern eastern region of Nigeria. Bolaji (2006) contends that apart from some Nigerian court actions proclaiming women's constitutional rights, there are other signs that the feminist movement in the country has made significant gains towards gender equality. In 
support of Bolaji (2006), Dibie and Dibie (2012) provided evidence that there has been increase number of women going to college and graduating with degrees in law, medicine, and other lucrative professional fields. There are more women pursuing careers and earning as much as men when compared to the situation in the 1970s. Many career women who are married despite the fact that they constantly experience sexual harassment have also achieved economic parity with their husbands. The number of women in elected positions has also incrementally doubled since 1999 (Dibie and Dibie, 2012).

The Federal Government of Nigeria's creation of a ministry of women affairs, the appointment of few women ministers, and the encouragement of women movement are considered steps in the right direction. However, most of these efforts as encouraging as they may be, do not seem to be addressing the discrimination that women face in urban and rural areas in the country every day (Dibie \& Uche, 2015). Women in Nigeria continue to do the derogatory jobs as they find it difficult to compete equally with their male counterparts for white colour job opportunities. As a result, the gender gap continues to widen especially in the northern parts of the country.

According to the Organization for Economic Co-operation and Development (OECD) report in (2010) Nigeria's women physical integrity is not sufficiently protected. Out of 36 states in the country, only nine states have a law in place that addresses violence against women. After almost seventy years since the country attained independence, its Penal Code still grants husbands permission to beat their wives, provided the violence does not result in serious injury. Further, the Nigeria's legal system is made of up of English common law, customary law, Islamic (Sharia) law and statutory law. Customary law is prevalent in the southern part whilst sharia law is widely made recourse in many of the states in the Northern states of Nigeria. Despite these legal systems, it is reported that domestic violence is common and affects one-fifth of couples (OECD, 2010). A Nigeria Demographic and Health Survey (NDHS) (2008) result shows that more than two-fifths of women (43\%) and almost one-third of men (30\%) agree that a husband is justified in beating his wife for certain reasons. Going out without telling him and neglecting the children are the two most commonly cited justifications for wife beating among both women and men. The NDHS (2008) survey also shows that $28 \%$ of women age $15-49$ have experienced physical violence since age 15 . Another $15 \%$ of women in the country have experienced domestic violence. These women report that their husband or partner 
is the person most often committing the violence. Seven percent of women age 15-49 have never experienced sexual violence. Physical violence varies by women's background characteristics. Women in urban areas are more likely than their rural counterparts to report having experienced physical violence since age 15 (OECD, 2010). A greater proportion of women living in South-South zone (52\%) have experienced physical violence compared to women in North East (20\%) and North West (13\%) zones respectively (NDHS, 2008). As a result, Nigerian women consider it normal to be beaten by their husband.

NGOs as used in this paper refer to those non-governmental organizations that are either foreign or domestic operating in Nigeria for the improvement of the lifestyle of a given society. These NGOs have contributed to moving women from their subordinate to a more visible role in all sphere of the country. Nigeria has a federal government, 36 states and 774 local governments. There are so many NGOs working with women to ensure and foster their effective participation in development. The question we beg to ask in this paper is that: can women empowerment, which is very important for their capacity building and effective participation in development, the government alone without other institutions attain women empowerment, which is very important for their capacity building and effective participation in development. In Nigeria, domestic and foreign NGOs have moved beyond mere designed of policies to strategic grassroots' techniques in helping the nation's women to fight discrimination, inequality and poverty.

Despite several years of interaction between the major religious groups in Nigeria, religion is still a major factor in the policy and politics of the state. Unfortunately for women in the county, the major religions in Nigeria still preach male superiority and domination (Ako-Nai, 2013). This has been the state of women affairs since the attainment of independence. For example, under Islamic and civil law, married women have the right and access to property other than land. Civil law entitles women to have access to land (Dibie and Dibie 2012; Ako-Nai, 2013). However, certain customary laws stipulate that only men have the right to own land. It is however a common practice for women to obtain land solely through marriage or family. The major area of discrimination is the customary law that denies women from any entitlement to household property or assets acquired by their husband.

The pursuit of happiness by women and girls has been hampered by prejudices and customs that conflict with Nigeria's Federal Government's commitment to human dignity, 
freedom, liberty, and democracy (Dibie and Atibil, 2012). For instance, women's freedom of movement is restricted in that they need their husband's permission to travel. In addition, Islamic women in purdah cannot leave their homes without permission from their husbands and must be accompanied by a man at all times when in public (Adeleke 2004; Ronke Ako-Nai 2013). In Muslim communities Purdah also restricts women's freedom to dress the way they wish. Sharia law requires women to be veiled in public whether the like or not.

The right of women to develop their capacities has not been fully protected in Nigeria. Several efforts to support major actions to protect women and girls from rape, domestic violence, and all forms of sex discrimination has not been equitably implement all over the country (Dibie and Atbil 20012). In some societies widows face the greatest degree of discrimination because they are often confined to the home and must keep their heads shaven and wear mourning dress.

According to Ronke Ako-Nai (2013) the nature of oppression and victimization of women in Nigeria differs from society to society or from tribe to tribe or from culture to culture even within the same region. Although, the various systems are exploitative and oppressive, they differ in many ways. She contends that as a result of the global nature of gender issues, women issues tend to be addressed through similar paradigm without adequately reference to the individual nature of the various entity or society.

Cultural, religious, social, economic, political and even colonial legacy have constituted factors that play dominant roles in shaping the participation of women in every aspect of human endeavour in the Nigerian society (Usua and Osuagwu, 2010). As a result there is a rigid division between male and female roles with the males being encouraged to participate in the more aggressive, competitive and independent ventures. The overall effect is that the men in Nigeria are properly positioned to benefit maximally from social opportunities, government facilities, and infrastructures (Adeleke, 2004).

Gender inequality in Nigeria involves three common concepts, i.e. inequality in prestige, social inequality, inequality in power - political inequality and inequality in access to or control over resources - economic inequality (Okojie, 1995). As Okojie depicts the picture above, men and women are unequal along many, social, economic and political dimensions. Although several NGOs have been networking internally and internationally to ensure women's emancipation and empowerment in various sectors in 
Nigeria, the nation's socialization process is still strongly based on patriarchal and matriarchy values that tends to promote polygamy. Islam is a major religion in Nigeria and it supports a man to have more than one wife. Just like their Muslim counterpart some Christian sects also embrace polygamy (Ako-Nai, 2013).

The goal of this paper is to investigate the performance of NGOs and the Federal Government of Nigeria in the empowerment of women in the country. It examines the following research questions: Is there a positive relationship between government policies and its inability to enforce domestic abuse crime, sexual harassment, and male hostile domination? Are NGOs women empowerment and women liberation programs more effective than those of the government? To address these questions, the study uses data on NGOs that provides major capacity building projects (i.e., women education, legal rights and entrepreneurship projects) and government programs for combating discrimination against women in the six geo-political zones in Nigeria. Interviews, questionnaires and focus group research methods were also used to evaluate the performance of the Government of Nigeria and NGOs with respect to the empowerment of women in the country. On one hand, results point toward a negative relationship between government and women empowerment policies. On the other hand, result shows a positive correlation between NGOs and women empowerment in Nigeria. Further cultural, religious, social and economic factors as well as the lack of effective implementation of gender policies continue to militate against the integration of women in the country. The results of this study have implications for NGOs management in the context of women projects management and governments' political willingness to collaborate with NGOs in addressing women's empowerment and capacity-building issues in Nigeria.

\section{Social Justice and Gender Framework}

The social justice theory is concerned about promoting a just society by confronting injustice and fostering ethical values and diversity. Social justice can be claimed to exist when all the people in a society or country share common humanity and therefore have a right to equitable treatment, support for their human rights, and a fair allocation of community resources (Rawls, 1971). Hosmer (2006) contends that in a country where social justice prevails citizens (women and men), are not discriminated against, nor are their welfare and well-being constrained or prejudiced on the basis of gender, sexuality, 
religion, political affiliations, age, race, belief, disability, location, social class, socioeconomic circumstances, or other characteristic of background or group membership (Ferrell et al. 2015).

The philosophy of John Rawls draws on the work of John Lock's (1960 \& 1689) social contract, the categorical imperative of Immanuel Kant (1797 \& 1999) and the utilitarian theory of Jeremy Bentham and John Stuart Mill and Rawls (2001). The theory of justice postulated that each person possesses an inviolability founded on justice that even the welfare of society as a whole cannot override. According to this theory, social justice involves promoting a just society by challenging injustice and valuing diversity (Sen 1997 $\&$ 2009). For this reason justice denies that the loss of freedom for some is made right by a greater good shared by others. In his theory of justice as fairness Rawls also envisions a society of free citizens holding equal basic rights cooperating within an egalitarian economic system. A key position of Rawls' theory is that the least-advantaged people should get the most help so they have a chance to succeed (Moellendorf 2002; Nussbaum 2000). The theory can be considered pluralistic or circumstantial because different parts of this conception of social justice are more or less relevant depending on the circumstances (Nickel 2000; Nozick, 1974).

This means social justice depends on the context of a given situations. Unfortunately, social and economic inequalities in several African countries have not been able to satisfy two conditions. First, women are not equitably attached to senior government and private business offices and positions. Further, senior government and private business positions are not accessible to women that are the least advantaged members of society in many African countries. In the context of discrimination against women Nussbaum (1999 \& 2000) pointed out that Rawls' conception of justice, like any conception of justice whatsoever, is an associational conception where women and men could equally relate. It is about relationships between members of an association or society. In addition, Moellendorf (2002) contends that cosmopolitan justice applies the approach Rawls (2001) developed for any country. This perspective may be understood as an economic association even if there is no effective international political association. Here the important point is that Rawls' initial concern with justice is related to relationships between women and men within a nation-state (Reiman, 1990). It is interesting to note that equitable relationship between men and women may also enhance empowerment. 
According to Dibie (2014) and Schirch (2012), the issue of equal participation of women and men is essential to the planning process and sustainable development of any country. However in many African countries several participatory processes including those that profess to deliver women empowered beneficiaries' fail significantly in this regards. In addition, Oakley et al. (1991) and Theron (2008) argues that two types of women empowerment occur. On one hand, women empowerments through the development of skills and abilities that can enable them to manage and better negotiate with the sustainable development and delivery system of the country. On the other hand, women empowerment is a process that can equip them to decide on and take action in terms of the development process. Therefore, in analyzing women empowerment and the fact that they are powerless in the men dominated society in Africa, there is the possibility to end at the paradox of power. This is because the expectation of the powerless women is determined both by circumstances and by the imposed expectations of the powerful men. As a result any changes that may occur will be affected by a change in attitude on the part of the powerless women not by circumstances as well as change in behaviour by the powerful men.

Liberal feminism theory argues that it is the democratic institutions of the state that will place women in the right pedestal of participation in society. This is because a 'country whose democratic traditions are strong empowers their women' (Inglehart and Welzel, 2005). Top on the agenda of liberal feminism is 'equality of opportunities for women' (Green, 1999). Liberal feminist theory focuses on women's inequality with men as it relates to sex, role, socialization and sexism (Hudson-Weems 1997; Smee and Woodroffe 2013). It contends that women's activities are confined to the private sphere and domestic roles ranging from child bearing, child-care to running the home. This has hindered women from participating fully in education, public service and even in politics like their male counterparts (Hudson-Weems, 1997). Hence liberal feminism contends that women should be given equal opportunities like men, and be allowed to participate without cultural constraints. Liberal feminism further contends that men and women are first and foremost human beings because they both have the capacity for reasoning. Women therefore, should be given access as men; that is, there is the need for a "level playing field" to be provided for both men and women where they can compete based on merit and ability and not on gender basis. 
Radical feminism postulates that women's domination has its root in patriarchy. The patriarchal nature of society makes it possible for power and privileges to reside with men. This is because, 'patriarchy is a gender arrangement that is characterized by male's domination of females' (Hudson-Weems, 1997; Inglehart and Welzel 2002). Thus radical feminists advocate that the society as a whole should be restructured in such a way that it will be possible for men and women to have equal opportunities. They advocate a resistance of violence against women in any form. Radical feminists tend to take an extreme position in their call for institutional and structural transformation. This puts them in an antagonistic position to men (Fallon, 2003).Their contention however is that the 'transformation should help to galvanize the consciousness of women's importance in any society (Dibie and Offiong, 2009). The expected result being a reconstruction of the relationship between men and women in a 'more egalitarian and ethical way'

Marxist feminism sees the imbalance in the relationship between men and women from an economic perspective. It contends 'that women's inequality is rooted in class oppression under capitalism' (Ferguson and Hennessy, 2010). Marxists feminists unequivocally condemn what they call the economic dependence of women which they argue has tied women to the apron strings of men. Marxist feminists therefore advocate that the activities of women either in the public service or domestic domains should be rated and remunerated and that women should be empowered economically (Vosel, 2013).

Although myths do not have any specific or logical worth or value, but over time, they have been employed to rationalize the denigration of women in Nigeria. Since society is dynamic, Marxist feminist advocates a 'reconstructing of society by transforming the gender myths. It is by so doing that the much talked about women empowerment and stable society for the realization of humanity's potentials (including women) can be achieved (Kolawole, 1988).

The reason for adopting this theory is because its underlying point is that without either gender, human society is incomplete. Therefore, women should not be seen as appendages to men; rather, they should be seen as the complimentary ultimate factor in societal equilibrium (Okpeh \& Angya 2007; Sha 2007). Women therefore like men need to be empowered in order to find meaning and fulfilment in life. This will eventually pay back to the society by way of total development and wellbeing of both men and women Figure 1 shows the relationship between feminist Theories and Women's Empowerment. 
Figure 1: The Relationship between Feminist Theories and Women Empowerment

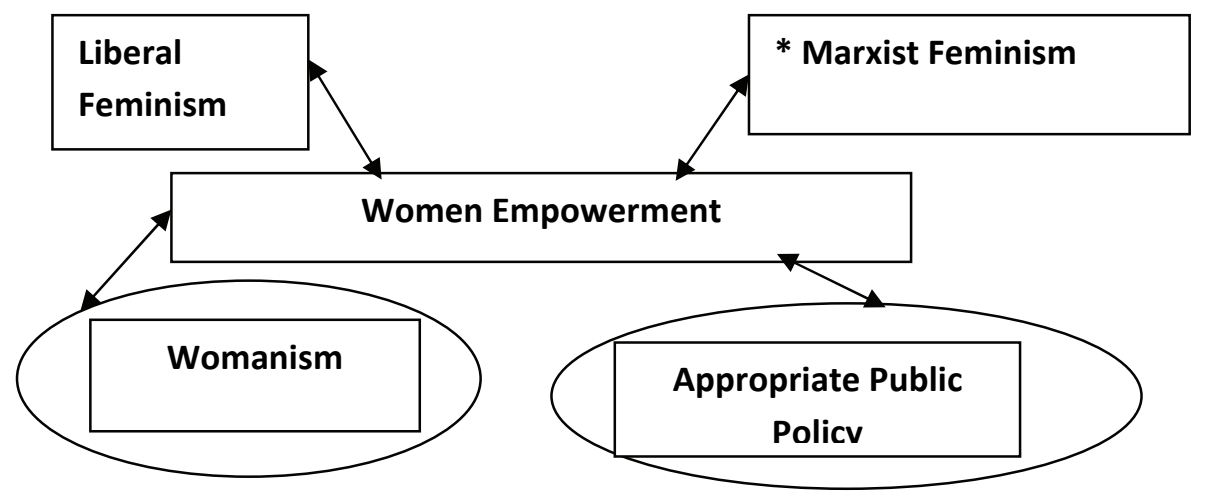

Source: Dibie J. and Dibie, R. 2012. "Non-Governmental Organizations (NGOs) and the Empowerment of Women in Africa." African and Asian Studies Journal, Vol. 11, no. 1, 95-122.

Womanism theory is essentially, advocates freedom and independence for the women who need to work in association with men to contribute their quota to the stability of the human society (Inglehart and Welzel, 2005). The theory addresses the racist and classist aspects of white feminism and actively opposes separatist ideologies. It includes the word "man", recognizing that black men are an integral part of black women's lives as their children, lovers, and family members (Walker 2012; Phillip 2006). Women therefore, like men, need to be empowered in order to find meaning and fulfilment in life.

According to Dibie and Atibil (2012) and Mahmond (2004) the difference in culture and perception brings up the question of whether the same theory could apply to societies with different cultures and religions. On one hand, in some western industrialized countries, Islam encourages the submission of women to men. On the other hand, in the Arab countries such submission is perceived as men protecting their wives. The present clash in civilization and unending acts of terror attest to this view. Further, in Africa, the nature of religion observed still determines the way the marriage system and polygamy are still widely practiced. Islam accepts polygamy and traditional religion also upholds it. In addition, it will be interesting to note that some Christian sects still practice and accept polygamy (Ako-Nai, 2013). In some regions of Africa matrilineal culture also give women both reproductive and productive responsibilities. 
For example the Ashanti (Akan) women along with the Queen mothers were powerful in pre-colonial Ghana (Dibie and Atibil, 2012). Before the British Government colonized Ghana, the female leaders among the Akan people of Ghana were very powerful. The colonial administration in Ghana almost destroyed this culture as a result of their imposition of the British value system.

The ambivalent and powerfully charged opposition of feminized tradition with masculinized public life constitute significant modernity that inform a seemingly disparate body of literature about development, modernity, dependency and women's role in sustainable development. According to Vasquez (1996) and Mingst (2004) theories are not static; they can sometimes lead scholars in the wrong direction of a debate. What is clear, however, is that human culture and ideologies are diverse and issues must not be looked at from narrow Western viewpoint only? Furthermore, most of the feminist theories proposed are formulated by men for women and some like Marxism were not expected or drawn for women struggle or oppression. Having made this argument, it will be fair to point out that, there are still positive and negative aspects of the African culture that international instruments and actions could help to bring about change in the way women are treated in the continent. The theories discussed earlier emphasize fairness and equity in gender policy decisions. The deontology theory for example refers to moral philosophies that focus on the rights of individuals including women and the intentions associated with a particular behaviour rather than its consequences (Ferrell et al. 2015). It is interesting to note that equitable relationship between men and women may also enhance empowerment. Fundamental to deontological theory is the idea that equal respect and opportunities must be given to women and men in the sustainable development and capacity building processes in Nigeria. The authors regard certain behaviours as inherently rights of women, and determination of this rightness focuses on the individual actor, not on the country or society.

\section{Methodology}

Nigeria is a country in West Africa. The nation is divided into six geopolitical zones. The United Nations (2012) estimates the population of Nigeria to be 170 million people, distributed as $51.7 \%$ rural and $48.3 \%$ urban, and with a population density of 167.5 people per square kilometre. The World Bank (2013) reported estimated the current 
population of Nigeria to be about 162.5 million. The only breakdown available was by gender: males numbered $71,709,859$, females numbered $68,293,086$. The rest of the populations are children. Nigeria is divided into six geo-political zones. The research was conducted in the six geopolitical zones of Nigeria namely, northeast, northwest, northcentral, south east, southwest and south-south. The major cities in the six geo-political zones include: Lagos in the South-West, Aba in the South-East, Port Harcourt in the South-South, Kano in the North-West, Jos in the North-East, and Abuja in the NorthCentral.

This study uses both qualitative and quantitative research methods to examine the role of government and NGOs in the empowerment of women in Nigeria. The qualitative aspect deals with interviews and focus group discussions while the quantitative aspect deals with the use of questionnaire. The dependent variable is NGOs women empowerment programs, while the independent variable is the benefits derived by women in the six geo-political zones in Nigeria.

A focus group meeting was held in each of the geo-political zones. Each focus group on women empowerment issues consisted of twenty participants drawn from several religious and church groups as well as government agencies personnel, and community members in Nigeria.

The study used a community engaged-participatory-action approach involving a Technical Church Board (TCB) and Women Christian Organization Board (WCOB). Discussions covered five questions developed by the Technical Church Board and validated by the Women Christian Advisory Board. The TCB were also responsible for recruitment and facilitating the focus group meetings.

The WCOB consisted of representation from women church committee members, including: women who have benefited from the services provided by the NGOs, female ministers, unmarried ladies that have been sexually harassed, female nurses, female police officers; elected female local government officials, female doctors, female lawyers, and female traders. The Technical Board consisted of pastors, evangelists, female counsellors in the NGOs directors and senior staff. In the Abuja focus group session senior staff of the Ministry of Women's Affairs where also invited to participate in the focus group discussion. 


\section{The hypotheses tested are:}

Hypothesis 1: There is a positive relationship between NGOs women empowerment programs and women liberation than government enhancement of women's power.

Hypothesis 2: There is a positive relationship between good empowerment programs and women contribution to the sustainable development of Nigeria.

Hypothesis 3: There is a positive relationship between education of women and girls and the breaking of the glass ceiling to enable women to succeed in their professional and economic activities.

Hypothesis 4: There is a positive relationship between culture and religion and domestic abuse of women in Nigeria.

Hypothesis 5: There is no relationship between married and single women bearing of children and employment outside the home.

Hypothesis 6: There is positive relationship between government policies and its inability to enforce domestic abuse crime, sexual harassment, and male hostile domination.

Hypothesis 7: There is a positive relationship between women's domestic responsibilities with regards to home and children and their ability to act as autonomous beings in the work place.

Selection of participants was based on six important criteria: (1) the link to a NGO or church; (2) previous experience of discrimination from men; (3) a member of an NGO that offer services in the promotion of equity for women and the enhancement of women contribution to sustainable development; (4) beneficial of the empowerment programs offered by NGOs; (5) officials of Ministry of Women Affairs and senior staff of several government agencies; and (6) member of law enforcement agencies and female lawyers.

The population of the study is made up of two categories. The first is the 153 NGOs that are registered with the Corporate Affairs Commission and also listed in a national directory published by the Federal Ministry of Women Affairs and Social Development as well as the Directory of OVC and CSOs in Nigeria. The second and last category consists 
of the 67,547 women who have benefited from the empowerment programs of these NGOs as contained in their 2010 Annual Report. From the second population category the sample size of 2,750 women beneficiaries of the services of these NGOs was selected using the snowball sampling technique for the administration of the questionnaire $(2,250)$, interview (300) and focus group discussion (20 people from each of the six geopolitical zones surveyed (120).

The focus group participants were chosen using a modified snowball sampling methodology, which was supported by NGOs Advisory Board (NAB). The NGOs Advisory Board was selected using a snowball sampling method. NAB members who invited additional participants during their church meetings, community events, via telephone calls, and house-to-house visits, then recruited focus group participants.

The data for this study were also derived from both primary and secondary sources. An extensive literature review and search for existing data and records about the empowerment of women issues was conducted. International nongovernmental organizations reports and outputs of several human right activities were consulted. Some secondary data were also generated from books, journal, research already conducted, and documents from associations of women from state agencies such as the Federal Ministry of Justice, the Federal Ministry of Statistics and the Federal Ministry of Women Affairs.

Some content analysis of the economic impact of discrimination of women was also conducted. Primary data were collected through the use of survey questionnaire, interviews and focus group discussions. The primary data collection was through surveys, administered in the six geo-political zones previously discussed in this paper. Two thousand two hundred and fifty $(2,250)$ copies of the questionnaire were administered in all the six geo-political zones. The respondents returned one thousand, five hundred and twenty-eight (1528) completed questionnaire. This represents a $68 \%$ response rate. Specific information on the impact of NGOs and government roles in the empowerment of women was obtained from the completed questionnaires.

The result of the study was organized into analysis matrix in order to summarize and develop typologies and descriptive statistics that link the findings to the research goals. The researcher also operationalized each of the impacts of women empowerment in Nigeria. The findings described the various roles played by NGOs in the empowerment of women in Nigeria. This paper used Statistical Package for the Social Sciences (SPSS) to 
measure and determine causality and linkages between discrimination against women and their empowerment programs. Other measures of correlation relationship include the ranked correlations coefficient, cross tabulation and percentages. For the purpose of this study, the researcher made use of percentages and correlation analysis.

\section{Data Analysis and Discussion}

The first objective of the paper is to determine the demographic characteristics of both the NGOs offering empowerment programs to Nigerian women and the dynamics of the recipients. Of the 1,528 respondents, $2.3 \%$ (35) are leaders who represented their organizations while $97.3 \%(1,493)$ are the beneficiaries of the services of NGOs spread across the country. The two samples were reached through the NGOs identified and other members using the snowball sampling technique.

Table 1 shows the age distribution of the respondents. The table indicates that for beneficiaries, 3.5\% (52) are of 60 years and above, 21.5\% (320) are between 50-59 years, $37.2 \%(555)$ are between 40-49 years, 24.7\% (369) are between 30-39 years while 13.2\% (29) are between 29 years and below. The table also indicates the age bracket of the leaders of the NGOs and government agencies that responded to the questionnaire thus: $10 \%$ (3) are between 60 years and below, 30\% (11) are between 50-59 years, 26\% (9) are between 40-49 years, 22\% (8) are between 30-39 years while 12\% (4) are between the age bracket of 29 years and below.

Table 1: Age Distribution of the Respondents

\begin{tabular}{|l|l|l|l|l|}
\hline \multirow{2}{*}{$\begin{array}{l}\text { Age } \\
\text { Bracket }\end{array}$} & \multicolumn{2}{|c|}{ Beneficiaries } & \multicolumn{2}{c|}{ Leaders of FBNGOs } \\
\cline { 2 - 5 } $\begin{array}{l}\text { 60 years } \\
\text { and } \\
\text { above }\end{array}$ & 52 & 3.5 & 3 & Frequency \\
\hline $50-59$ & 320 & 21.5 & 11 & 10 \\
\hline $40-49$ & 555 & 37.2 & 9 & 30 \\
\hline $30-39$ & 369 & 24.7 & 8 & 26 \\
\hline $20-29$ & 197 & 13.2 & 4 & 22 \\
\hline Total & $\mathbf{1 4 9 3}$ & $\mathbf{1 0 0 . 0}$ & $\mathbf{3 5}$ & 12 \\
\hline
\end{tabular}

Field Survey, 2013-2014 
Table 2 below reveals the distribution of the respondents according to their geopolitical zones. Beneficiaries are in the following order: $7.5 \%$ (113) are from the North East; $7.9 \%$ (118) are from the North West; $21.4 \%$ (320) are from the North Central; $19.9 \%$ (298) are from the South East, 21.6\% (323) are from the South West while 21.5\% (321) are from the South-South. Table 3 above shows how the 1493 beneficiaries rated the types of NGO that best meet their needs. As shown in the table, 10.9\% (163) of the respondents indicated NGOs with no religious affiliation, 55.5\% (829) indicated those with church affiliation, $14.5 \%$ (216) indicated those with international or foreign affiliation, $14.1 \%$ (211) indicated those with inter-religious affiliation while $5.0 \%$ indicated those with no international affiliation.

Table 2: Geopolitical Zones of the Respondents

\begin{tabular}{|l|l|l|l|l|}
\hline \multirow{2}{*}{ Zones } & Beneficiaries & \multicolumn{2}{|c|}{ Leaders } \\
\cline { 2 - 5 } & Frequency & Percent & Frequency & Percent \\
\hline North-East & 113 & 7.5 & 3 & 8.6 \\
\hline North-West & 118 & 7.9 & 3 & 8.6 \\
\hline North-Central & 320 & 21.4 & 7 & 20 \\
\hline South-East & 298 & 19.9 & 7 & 20 \\
\hline South-West & 323 & 21.6 & 8 & 22.8 \\
\hline South-South & 321 & 21.5 & 7 & 20 \\
\hline Total & $\mathbf{1 4 9 3}$ & $\mathbf{1 0 0 . 0}$ & $\mathbf{3 5}$ & $\mathbf{1 0 0}$ \\
\hline
\end{tabular}

Field Survey, 2013-2014

Table 4 shows the social group affiliations of the respondents. The table shows that $11.1 \%$ (165) of the respondents are farmers, $22.3 \%$ (333) are traders, $32.4 \%$ (484) are professional women including teachers and government administrative staff; $31.2 \%$ (466) are Christian and Muslims members while 3.0\% (45) do not belong to any religious group. 
Table 3: Beneficiaries' Rating from NGO that best meet their Needs

\begin{tabular}{|l|l|l|}
\hline Rating of NGOs & Frequency & $\begin{array}{l}\text { NGOs } \\
\text { Percent }\end{array}$ \\
\hline $\begin{array}{l}\text { Nongovernmental organization (NGO) with no religious } \\
\text { affiliation }\end{array}$ & 163 & 10.9 \\
\hline Nongovernmental organization affiliated with church & 829 & 55.5 \\
\hline $\begin{array}{l}\text { Nongovernmental organization with international or } \\
\text { foreign affiliation }\end{array}$ & 216 & 14.5 \\
\hline $\begin{array}{l}\text { Nongovernmental organization with inter-religious } \\
\text { affiliation }\end{array}$ & 211 & 14.1 \\
\hline $\begin{array}{l}\text { Nongovernmental organization with no international } \\
\text { affiliation }\end{array}$ & 74 & 5.0 \\
\hline Total & $\mathbf{1 4 9 3}$ & $\mathbf{1 0 0 . 0}$ \\
\hline
\end{tabular}

Field Survey, 2013-2014

The second objective is to examine the type of empowerment programs that government and NGOs have put in place for the benefit of Nigerian women. Table 5 below shows the type of services that the NGOs render to women. The table shows that $71.4 \%$ (25) of the respondents are engaged in mainly women empowerment services, $17.1 \%$ (6) of the respondents are engaged in mainly advocacy services, while $11.4 \%$ (4) of the respondents are engaged in mainly government policy related services.

\section{Table 4: Group Affiliations of the Respondents}

\begin{tabular}{|l|l|l|}
\hline Group & Frequency & Percent \\
\hline Farmer & 165 & 11.1 \\
\hline Trader & 333 & 22.3 \\
\hline $\begin{array}{l}\text { Professional woman including } \\
\text { teacher/Administrative staff and so on }\end{array}$ & 484 & 32.4 \\
\hline Church member & 466 & 31.2 \\
\hline Non-religious group member & 45 & 3.0 \\
\hline Total & $\mathbf{1 4 9 3}$ & $\mathbf{1 0 0}$ \\
\hline
\end{tabular}

Field Survey, 2013-2014 
In rating the type of benefits which the beneficiaries derive from the empowerment programs of government and NGOs, Table 5A above shows that $19.6 \%$ (293) indicated training on family health and care, $24.3 \%$ (307) indicated training on home management, $12.5 \%$ (187) indicated training in political awareness, 20.6\% (436) indicated training in Entrepreneurship, 19.4\% (290) indicated training on Women's Human Rights while 3.6 (53\%) indicated training on peace building. Table 5B also shows that the respondents tend to benefit more from NGOs women empowerment programs than similar training organized by the federal and state governments of Nigeria.

Table 5A: Type of benefit derived from the services of NGOs and Government

\begin{tabular}{|l|l|l|l|}
\hline Types of Benefits & Frequency & $\begin{array}{l}\text { NGO } \\
\text { Percent }\end{array}$ & $\begin{array}{l}\text { Government } \\
\text { Percent }\end{array}$ \\
\hline Training on family health and care & 293 & 19.6 & 17.0 \\
Training on Home Management & 363 & 24.3 & 21.5 \\
Training in Political awareness & 187 & 12.5 & 11.0 \\
Training in Entrepreneurship & 307 & 20.6 & 18.0 \\
Training on Women's Human Rights & 290 & 19.4 & 17.8 \\
Training on Peace Building & 53 & 3.6 & 14.7 \\
Total & 1493 & 100.0 & 100.0 \\
\hline
\end{tabular}

Field Survey, 2013- 2014

Table 5B: Respondent Rating of the Services that Government and NGOs

Provided

\begin{tabular}{|l|l|l|l|l|}
\hline Types of Services & $\begin{array}{l}\text { Total } \\
\text { Number }\end{array}$ & $\begin{array}{l}\text { NG0s } \\
\text { Programs \% }\end{array}$ & $\begin{array}{l}\text { Government } \\
\text { Programs \% }\end{array}$ & Total \% \\
\hline $\begin{array}{l}\text { Promotion of equity for } \\
\text { women }\end{array}$ & 215 & 10.4 & 4.0 & 14.4 \\
\hline $\begin{array}{l}\text { Enhancement of women's } \\
\text { contribution to Sustainable } \\
\text { development }\end{array}$ & 19.9 & 8.0 & $27-9$ \\
\hline $\begin{array}{l}\text { Promotion of self- } \\
\text { actualization for women }\end{array}$ & 309 & 12.7 & 8.0 & 20.7 \\
\hline $\begin{array}{l}\text { Sharing of God's love for } \\
\text { women that have been } \\
\text { decimated }\end{array}$ & 436 & 22.0 & 7.2 & 29.2 \\
\hline Building good society & 411 & 4.8 & 3.0 & 7.8 \\
\hline Total & $\mathbf{1 , 7 8 8}$ & & & $\mathbf{1 0 0}$ \\
\hline
\end{tabular}

Field Survey, 2013- 2014 


\section{Secondary Research Outcome:}

The data in Tables 8 up to 14 were generated from secondary sources such as books, journal, research already conducted, and documents from the Federal Ministry of Statistics, and the Federal Ministry of Women Affairs. I used the empowerment services provided by the NGOs in table 17 and 18 to test the following hypothesis.

Hypothesis 1: There is a positive relationship between the services of NGOs and the empowerment of Nigerian women.

Secondary data reveals that approximately 67,547 women have benefited from NGOs women empowerment programs. The average number of Christian women that have been empowered by faith-based NGOs ranges from 862 to 1,317. There were fewer than ten government sponsored women empowerment programs in the North Central geopolitical zone. Thus, the finding in this geo-political zone is that NGOs are doing more to empower women than the federal and state governments do. The findings also indicate that government policy on equality does not have the same impact on women as it does on men. Women often participated in NGOs empowerment programs and social gatherings than in politics. As a matter of fact women participated in political activities in different ways when compared to men. Addressing these differences has important implication for the study of gender equality in Nigeria.

An average of 540 women tends to have benefitted from the various empowerment programs organized by NGOs in the southern geo-political zones. In more Islamic geopolitical zones, NGOs tend to be the major vehicle for the zones to galvanize women participation to gain social and religious representation. While women in the geopolitical zone tend to participate in greater number in NGOs empowerment programs their average percentage rate range from 37 to 59. Generally women in the northern geo-political zones participated more in Islamic NGOs than Christian women organization. Women in the northern geo-political zones are largely excluded from key areas such as economic policy and political affairs.

Many women are constrained by their roles in the private sphere which prevent them from participating in the NGOs empowerment programs. Lack of participation tends to prevent them from gaining the experience deemed necessary for career in politics and business. However, our research shows that this affects middle and upper 
Government and NGOS Performance with Respect to Women Empowerment in Nigeria 111

class women to a lesser extent because they can utilize the labour of female servants to free them from domestic representations.

\section{Primary Research Outcome - Questionnaire:}

Findings so far based on the secondary data show that whatever activities NGOs were involved in, they affect the lives of women even if they are not specifically dedicated to women's empowerment. Many of their programs are in poverty alleviation, economic development, education, human rights, environmental protection, and the provision of healthcare, including tackling HIV/AIDS. All of these benefit the whole society, including women. A large number of NGOs focus on issues that are pertinent to women's advancement.

In the light of the above, this segment of the work will discuss the primary data the researcher collected for this work through the use of questionnaire, interview and focus group discussion beginning with the questionnaire. A total of one thousand, five hundred and twenty eight women responded to the questionnaire out of which thirty five are women leaders while one thousand four hundred and ninety three are women that benefitted from the services of the NGOs. These data formed the basis for addressing the research questions and the hypotheses formulated for the study.

Significant findings in respect of Research Question one are in the areas of length of period NGOs have been in existence, the social background of the women that have benefitting from the services of NGOs as well as the age bracket of these women. This first research question states thus: What are the demographic characteristics of the NGOs offering empowerment programs to Nigerian women and the women recipients?

On how long the NGOs offering empowerment services to women in Nigeria have been in existence, the findings in this research indicate that the highest number of NGOs (92.1\%) has not existed for a period of more than thirty years. This is graphically represented in Figure 2 with the use of a pie chart. 
Figure 2: Pie Chart showing how long the NGOs have been in existence

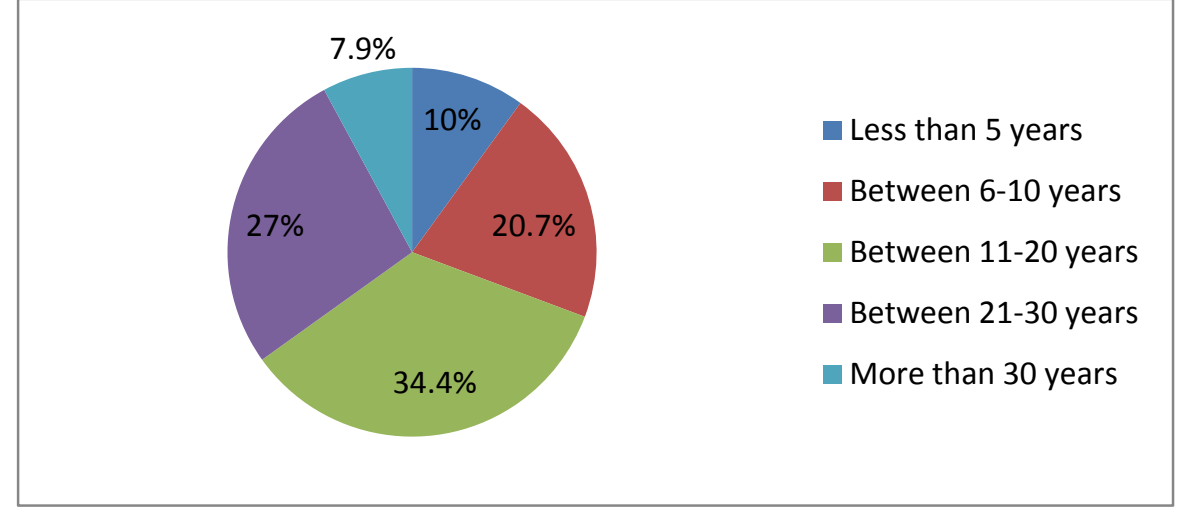

Figure 3: Histogram showing the age of the NGOs beneficiaries and their leaders



It means that NGOs as a factor for sustainable development in Nigeria is not an old phenomenon. Interestingly even the age bracket of the beneficiaries fall mainly between thirty to fifty years of age. A possible explanation to this could be that at the time these 
Government and NGOs Performance with Respect to Women Empowerment in Nigeria 113

NGOs were being put in place the current beneficiaries were also being born and both the service organ and the recipients are of the same generation. Related to this is the age bracket of even the leaders of these NGOs. They also are within the age range of thirty-fifty. The histogram in Figure 3 enhances this point.

This makes up $78 \%$ of the total age bracket of the women leaders that responded to the questionnaire. One would have expected that these leaders should be of advanced age but the reverse is the case. The researchers therefore conclude that NGOs, a fairly new phenomenon in Nigeria is empowering young Nigerian women through their leadership in establishing more effective capacity building programmes than the government of the country. These findings have great implications as the women beneficiaries can easily identify with the leadership of NGOs than those of the government. Furthermore, these leaders and beneficiaries are within the most vibrant and productive age bracket of the nation's population (Federal Ministry of Justice, 2008). Research question two asks thus: What type of empowerment programmes has the NGOs and government put in place for the benefit of Nigerian women?

In Nigeria a top-down transfer of women empowerment has not occurred through vision, mission, policy and principles, like conditionality, blueprints that have proved successful for women in Europe and North America. Discrimination against women has been one of the major social and welfare problems in Nigeria (Bolaji, 2006). Women in Nigeria have not been able to inherit land or earn properties through their personality, position and power. NGOs however projected that women will achieve this in the near future through appropriate public policy by government, financial status, social and political position and rank, and through affiliation to civil society groups movement. It is with this understanding that the discussion on the type of empowerment programs NGOs put in place for the benefit of Nigerian women is being presented here. The types of services that NGOs provided include (1) Women's Human Rights; (2) Economic Empowerment; (3) Political Participation; (4) Health and Reproductive Rights; (5) HIV/AIDS prevention and test; (6) Peace Building; and (6) Capacity building. This was substantiated by using the correlation analysis to determine the extent of the relationship between the two variables - services of NGOs and empowerment thus from the respondents' views as indicated in the questionnaire: 
Table 6: Correlation Analysis of the NGOs Services and Women Empowerment

\begin{tabular}{|l|l|l|l|l|l|}
\hline \multicolumn{1}{|c|}{ Variables } & Correlation(r) & Mean & St.d & P & Remark \\
\hline $\begin{array}{l}\text { Services of } \\
\text { FBNGOs }\end{array}$ & \multirow{2}{*}{$\mathbf{0 . 6 2 1}$} & 4.37565 & 1.24361 & 0.002 & Significant \\
\cline { 1 - 3 } $\begin{array}{l}\text { Women } \\
\text { Empowerment }\end{array}$ & & 1.37565 & 0.48738 & & \\
\hline & & & & & \\
\hline
\end{tabular}

The result above shows a strong positive relationship between the services of the NGOs and women empowerment. This was tested using correlation analysis thus: 0.621 at $p<0.05$ with Mean value of 4.37565 and Standard Deviation of 0.48738 for the first variable while the second variable has Mean value of 1.37565 and Standard Deviation of 0.48738. Therefore, $\mathrm{H}_{1}$ which states thus: There is a positive relationship between NGOs programs/ Services and women empowerment in Nigerian is accepted. This agrees with the secondary data analysis which indicated that the services of NGOs are impacting on Nigeria women than those of the government.

Research question three is phrased thus: To what extent are the services of NGOs positively impacting Nigerian women? NGOs in Nigeria from the research indicated the types of services they offer women are mostly on women empowerment. This accounts for 71 per cent of their programs. These services range from entrepreneurial training, training on women's human rights (awareness of their right to control their earnings, encouragement to work outside the home after years of abuse from spouses; enlightenment on filing suit to secure custody of children from courts). Previous tables give more details on these services. The ratings of the benefit and support received by beneficiaries of the services of NGOs are 87 per cent and 79 per cent respectively. To further buttress this fact, the correlation table below is tested.

Table 7 Correlation analysis of Women Empowerment Programs and Sustainable Development

\begin{tabular}{|l|l|l|l|c|c|}
\hline \multicolumn{1}{|c|}{ Variables } & Correlation(r) & Mean & St.d & P & Remark \\
\cline { 1 - 4 } $\begin{array}{l}\text { Women } \\
\text { Empowerment }\end{array}$ & $\mathbf{0 . 4 5 1}$ & 1.37565 & 0.48738 & 0.032 & Significant \\
\cline { 1 - 4 } $\begin{array}{l}\text { Sustainable } \\
\text { development }\end{array}$ & & 2.37565 & 0.52932 & & \\
\hline \multicolumn{1}{|c|}{1493} & & \\
\hline N & & \multicolumn{3}{|c|}{14932} \\
\hline
\end{tabular}


The result above shows a positive relationship between women empowerment and sustainable development in Nigeria. This was also tested using correlation analysis thus: 0.451 at $p<0.051$ th Mean value of 1.37565 and Standard Deviation of 0.48738 for the first variable while the second variable has Mean value of 2.37565 and Standard Deviation of 0.52932 . From this result the $\mathrm{H}_{1}$ is which states thus: There is a positive relationship between good empowerment programs and women's contribution to the sustainable development of Nigeria is calculated thus: accepted.

Administering questionnaire on the social impact of NGOs have enabled the author to conduct a systematic comparison of how the empowerment of women has contributed positively to sustainable development processes to Nigeria, and service provisions in lieu of NGOs and government. Had it not being for the women empowerment programs of NGOs and government in Nigeria, women would have been left in the cold. Hence Amali (2000) and Batliwala \& Deepa (2007) confirm this very important role of these groups as being able to "... identify the felt needs of communities" (Amali, 2000). The government is not keeping to its submissions on the Millennium Development Goals tree and five on empowering women for sustainable development. This is responsible to a large extent to Nigeria's slowness in achieving development that is sustainable. For a country whose large population (48\%) is not a major concern of the government so much such that women in Nigeria are still not in the mainstream in political, economic or even religious and traditional spheres of the society.

Research question four deals with possible inhibitory factors on the efforts of the NGOs to empower Nigerian women hence it is stated thus: What factors could inhibit the success of empowerment programmers offered by NGOs to Nigerian women? NGOs funds to run their programs came through two major sources i.e., fees for women's activities and donations from their churches. The government funds were derived from taxes. Table 7 reveals that 65.1 per cent of the funds NGOs use come from these sources other than government or the organized private sector. This implies that FBNGOs are autonomous and self-reliant and do not look up to the government to sponsor their programs. This also means that they encounter little or no direct interference in their programs since no outside body is in direct control through disbursement of funds or refusal to do so. Further, it allows them to maintain their focus as they run their programs towards achieving their mission and vision statement. 
The NGOs in Nigeria are also facing a major problem as the research discovered that the governments-local, state and federal do not render any significant support to them. This is revealed on table 8 where 47 per cent of the NGOs said they do not receive any form of support at all from local, state or federal government. Another 27 per cent of NGOs said they receive only minimal support from either of these levels of government. In clear terms one could say that 74.3 per cent of NGOs in Nigeria run their programs with little or no support from the government. This is a disturbing finding of this research as it implies that Nigerian women do not have confidence in the government's commitment to help them in their quest for empowerment and self-actualization.

Engagement with the state governments however has brought complex and contradictory outcomes, often not the ones intended. The nature of the relationship between women's movement and the local, state and federal governments is another key area for investigation in Nigeria. This collaboration will enable a better understanding of the strategies, which can be employed to enter the partnership, and opportunities that exist in different political formation. A possible reason for this could be that since NGOs are affiliated to different churches their source of funding is different as well as their service delivery programs to women.

Another challenge the NGOs in Nigeria encounter is in the area of collaboration. Most of the NGOs do not collaborate with others in order to achieve their goal of empowering women in Nigeria. Instead of collaboration, they engage themselves rather in competition, which is not helping them compliment one another's efforts towards sustainable development (Batliwala \& Deepa, 2007). Table 8 indicates that 69 per cent of the NGOs do not collaborate. This is a not a good sign for the sustainability of their services to women and their existence as a whole. Rather NGOs can collaborate in many ways to help women contribute to the national productivity output. Their collaboration could develop new approaches to old problems, recommit to quality, demonstrate a concern for equal rights and method, improve use of time to reduce the cost of what is done, and contribute to the pleasantness of the environment (Chandaria 2006; Cloe \& de Coning 2011). Women public productivity improvement requires an infusion of professionalism in public management. The public interest is intimately related to administrative decisions that will give women direction and meaning in all they do. 
This intended collaboration could involve the moral duty and obligation on the part of the public and private sectors' administrators to contribute to a variety of sustainable development issues in Nigeria.

On the side of the beneficiaries the challenge they find very common to them is the fact that NGOs lack funds to run their programmers. Table 8 shows that 60 per cent of the beneficiaries identified this need in NGOs. This corroborates the view of NGOs on the need for support from the government and as well as the fact that they are not encouraged to maximize their full potentials in pursuing their goal of empowering women in Nigeria. Whatever level of help they are rendering today could be improved if the funds to run their programmers are made available by both the federal and state governments of Nigeria.

\section{Primary Research Outcome - Interviews:}

A total of three hundred women were interviewed. Specific information on the impact of NGOs' role in the empowerment of women was obtained from the interview. Further information on the contribution of women to the sustainable development process was also collected. The following hypotheses were tested:

Hypothesis 3: There is a positive relationship between education of women and girls and the breaking of the glass ceiling to enable women to succeed in their professional and economic activities.

Hypothesis 7: There is a positive relationship between married and single women bearing of children and employment outside the home.

The interview revealed that cultural change and political socialization are closely related in Nigeria in the past four decades. It also revealed that agents of socialization such as family, schools, workplace, church, NGOs, government, peer groups, and media have played major roles in the empowerment of women and their social transformation. The tremendous cultural changes that have occurred in Nigeria in the past three decades have helped to shape all of these agents and have also affected women's economic and professional transformation. Women's professional transformation has also contributed to the sustainable development process in Nigeria positively. 
More than sixty percent of the women interviewed indicated that they were employed full-time, year-round. Eighty-three percent of the respondents indicated that employment outside the home is now the norm for them. Some of the interviewees made statements such as "I am very anxious for my baby to grow so I can look for a job". Although educated women (72 percent) are more likely than uneducated women (49 percent) to work outside the home. Even women with less than a master's degree education level are now more likely (50 percent) to be employed than not. Eighty-seven percent of the women interviewed hold university degrees and work outside their homes. Sixty-five percent of the respondents that are married indicated that they had jobs outside their home. In the course of the interview some of the women said "... although I am married, my work still continues, marriage does not stop work". Over sixty-two percent of the respondents that are married with children under the age of six had employment outside their homes. Another seventy-one percent of respondents who are single women with children under the age of six were also employed outside the home. These groups of women almost unanimously agreed that their ignorance of their right in the past made them suffer discrimination as single mothers, but now they are bold enough to say "I am not ashamed to carry my child to a Day Care centre while I go to work."

It is interesting to note that only thirty percent of the respondents tend to define themselves in terms of traditional roles. Furthermore, only three percent of women and men who continue to hold traditional views regarding women and politics are less likely to vote. These group respondents are also less likely to be active in political campaigns and organizations concerned with sustainable development and national problems. These category of people have the strong feeling that they do not matter in the decision making of the nation, even their votes to them are not necessary, they believe that "no woman can become the leader of Nigeria." Where are the Nigerian men that women should now take control of even politics?" Some of the respondents indicated that "they do not believe in this women thing, let married women continue to take care of their children and cook good food for their husbands." Thus, only three percent of the respondents are less likely to be politically active than with more modern socialeconomic ideas for national development of Nigeria.

The main findings of the interview is that gender consciousness focus on the recognition that one's relationship to the political world is shaped in important ways by 
Government and NGOs Performance with Respect to Women Empowerment in Nigeria 119

physical fact of one's sex will not lead all women to adopt the same political and economic positions. However, it is necessary if women, who were once denied the opportunity of economic and political participation because of their gender, are to understand that being female has political significance and to act accordingly. What is clear is that women's economic and political participation increase as women's consciousness of themselves as a group increases (Fallon, 2003). NGOs and the governments of Nigeria have all contributed to the efforts to help women develop gender consciousness. However, NGOs seem to be doing more in some geo-political zones than the government. One limitation however, is that NGOs do not have the power to enact gender public policies in the country hence they have been trying to influence the policy making process.

The interviews conducted confirmed the three hypotheses that:

(1) there is a relationship between good empowerment programs and women contribution to the sustainable development of Nigeria;

(2) there is a relationship between education of women and girls and the breaking of the glass ceiling to enable women to succeed in their professional and economic activities; and

(3) there is no relationship between married and single women bearing of children and employment outside the home.

A striking finding of our survey is that in the South-west, South-South and South-East where diversity is somewhat a higher priority, executives also report a higher share of women in their senior ranks. At government and private companies where gender diversity is a top-three agenda priority item, 87 percent of respondents report that more than 15 percent of their senior administrators were women; only 64 percent of those whose ministry or private companies rate diversity as a top-ten item, and 55 percent of all respondents, say the same. There is also some geographic variability: respondents in Federal Ministries or agencies in North-Central geo-political zones indicated that gender diversity is a top-ten agenda item for their organizations (35 percent and 34 percent, respectively) than those in North-West and North-East geo political zones.

There is an indication in Nigeria that support for gender consciousness will increase among women as more of them experience the impact of changes in the traditional roles of wife and mother. As women continue to share experiences at home, school, and 
work, these psychological bonds may contribute to the development of gender consciousness. The interview data supported hypotheses 3, 4 and 7: There is a positive relationship between education of women and girls and the breaking of the glass ceiling to enable women to succeed in their professional and economic activities. Further, the interview data shows that there is a positive relationship between married and single women bearing of children and employment outside the home and the last one says there is a positive relationship between married and single women bearing of children and employment outside the home. More than sixty percent of the respondents who are married and have children work outside their homes.

\section{Primary Research Outcome - Focus Group Discussion}

One other source of primary data collection was the use of focus group. A focus group meeting was held in each of the six geo-political zones of Nigeria. Each focus group on women empowerment issues consisted of twenty participants drawn from several religious and church groups as well as government agencies personnel, and community members in Nigeria. The study used a community engaged-participatory-action approach involving a Technical Church Board (TCB) and Women Christian Organization Board (WCOB). Discussions covered five questions developed by the Technical Church Board and validated by the Women Christian Advisory Board. The focus group discussion tested the following two hypotheses:

Hypothesis 4: There is a positive relationship between culture and religion and domestic abuse of women in Nigeria.

Hypothesis 5: There is positive relationship between government policies, its inability to enforce domestic abuse crime, sexual harassment, and male hostile domination on women

Hypothesis 6: There is a positive relationship between women's domestic responsibilities with regards to home and children and their ability to act as autonomous beings in the work place.

Tables 8 and 9 below present the number of statements made by focus group participants for each focus group question. It also presents the data analysis grid including the question, the domain of the question, the theme, the sub theme, original 
statements and potential research implications of participants' responses. Overall, 120 participants attended the focus group meeting (male $=30 \%$ and female $=70 \%$ ) aged twenty years and above. In all, 3,720 statements were collected and transcribed. These statements were divided into the question numbers that were asked.

In addition, the technology divides between this low income women and fairly educated women represents a continuous source of disparity in gender consciousness in Nigeria. Findings of lack of knowledge of various types of domestic abuse and the impacts on women; as well as inappropriate policies to address the nature of the crime against women are consistent with other findings in the literature (Adeleke 2004; Ezeilo 2006; Dibie \& Offiong 2009; Conway, et al. 2005). Other domestic abuse studies have found low levels of knowledge and preventive activity for this inhuman treatment of women (Odumosu et al 2009; Ojobo 2008; Kalu 1996; Dibie \& Dibie 2012).

The focus group discussion reveals that domestic violence and abuse can happen to anyone, regardless of size, gender, or strength, yet the problem is often overlooked, excused, or denied. This is especially true when the abuse is psychological, rather than physical. Emotional abuse is often minimized, yet it can leave deep and lasting scars. The respondents indicated that noticing and acknowledging the warning signs and symptoms of domestic violence and abuse is the first step to ending it. No one should live in fear of the person they love. If you recognize yourself or someone you know exhibiting warning signs and descriptions of abuse, don't hesitate to reach out.

Table 8: Sample Focus Group Questions and Response

\begin{tabular}{|c|l|c|c|c|c|}
\hline No & \multicolumn{1}{|c|}{ Questions } & $\begin{array}{c}\text { Affected } \\
\text { Statement }\end{array}$ & $\begin{array}{c}\text { Not Affected } \\
\text { Statement }\end{array}$ & Neutral & Total \\
\hline 1 & $\begin{array}{l}\text { What do we know about } \\
\text { domestic abuse? }\end{array}$ & 76 & 40 & 4 & 120 \\
\hline A & Physical abuse & 81 & 32 & 7 & 120 \\
\hline B & Physical violence & 101 & 12 & 7 & 120 \\
\hline C & Sexual abuse or harassment & 95 & 18 & 7 & 120 \\
\hline D & Dominance & Yes 113 & No 6 & 1 & 120 \\
\hline E & $\begin{array}{l}\text { How do we prevent it? Enact } \\
\text { Policy to Prosecute offenders }\end{array}$ & & & & 600 \\
\hline & & & & & \\
\hline 2 & $\begin{array}{l}\text { What do we know about } \\
\text { economic abuse? }\end{array}$ & & & & \\
\hline
\end{tabular}




\begin{tabular}{|c|c|c|c|c|c|}
\hline $\mathrm{A}$ & $\begin{array}{l}\text { Prevent woman from work } \\
\text { outside the home }\end{array}$ & 20 & 100 & 0 & 120 \\
\hline$B$ & $\begin{array}{l}\text { Control a wife's or girlfriend's } \\
\text { finances }\end{array}$ & 37 & 81 & 2 & 120 \\
\hline $\mathrm{C}$ & Withholding money & 19 & 100 & 1 & 120 \\
\hline $\mathrm{D}$ & $\begin{array}{l}\text { Making wife account for money } \\
\text { spent }\end{array}$ & 23 & 97 & 0 & 120 \\
\hline $\mathrm{E}$ & $\begin{array}{l}\text { Withholding basic necessities } \\
\text { food, clothes }\end{array}$ & 43 & 86 & 1 & 120 \\
\hline \multirow[t]{2}{*}{$\mathrm{F}$} & $\begin{array}{l}\text { How can we prevent these } \\
\text { economic abuses? Enact Policy } \\
\text { to Prosecute offenders }\end{array}$ & Yes 117 & No 2 & 1 & 120 \\
\hline & & & & & 720 \\
\hline 3 & $\begin{array}{l}\text { What do we know about } \\
\text { emotional abuse? }\end{array}$ & & & & \\
\hline$A$ & Naming calling & 84 & 32 & 4 & 120 \\
\hline$B$ & Blaming & 83 & 32 & 2 & 120 \\
\hline $\mathrm{C}$ & Shaming & 101 & 19 & 0 & 120 \\
\hline $\mathrm{D}$ & Yelling & 101 & 17 & 2 & 120 \\
\hline$E$ & Isolation & 37 & 83 & 0 & 120 \\
\hline $\mathrm{F}$ & Intimidation & 90 & 30 & 0 & 120 \\
\hline $\mathrm{G}$ & Controlling & 81 & 30 & 9 & 120 \\
\hline \multirow[t]{2}{*}{$\mathrm{H}$} & $\begin{array}{l}\text { What can we do about emotional } \\
\text { abuse? Enact Policy to Prosecute } \\
\text { offenders }\end{array}$ & Yes 98 & No 21 & 1 & 120 \\
\hline & & & & & 960 \\
\hline 4 & $\begin{array}{l}\text { What do we know about religious } \\
\text { and cultural discrimination? }\end{array}$ & & & & \\
\hline$A$ & $\begin{array}{l}\text { Forcing women to cover their } \\
\text { faces }\end{array}$ & 28 & 91 & 1 & 120 \\
\hline$B$ & $\begin{array}{l}\text { Forcing women and girls to be } \\
\text { circumcised }\end{array}$ & 27 & 91 & 2 & 120 \\
\hline $\mathrm{C}$ & $\begin{array}{l}\text { Forcing girls to get married at } \\
\text { early age }\end{array}$ & 77 & 37 & 6 & 120 \\
\hline $\mathrm{D}$ & Not educating girls or women & 26 & 92 & 2 & 120 \\
\hline \multirow[t]{2}{*}{$E$} & $\begin{array}{l}\text { What can be done about these } \\
\text { discriminations? Enact Policy to } \\
\text { Prosecute offenders }\end{array}$ & Yes 118 & No 2 & 0 & 120 \\
\hline & & & & & 600 \\
\hline 5 & $\begin{array}{l}\text { What policies are needed to } \\
\text { prevent these forms of abuses } \\
\text { and discriminations? }\end{array}$ & & & & \\
\hline A & Gender Issues to be addressed & All 120 & None 0 & 0 & 120 \\
\hline$B$ & $\begin{array}{l}\text { How to establish the appropriate } \\
\text { policies - Put pressure on elected } \\
\text { political leaders }\end{array}$ & Yes 118 & No 2 & 0 & 120 \\
\hline
\end{tabular}


Government and NGOs Performance with Respect to Women Empowerment in Nigeria 123

\begin{tabular}{|c|l|c|c|c|c|}
\hline C & $\begin{array}{l}\text { Who should implement the } \\
\text { policies? Government and NGOs }\end{array}$ & Govt. 80 & NGOs 50 & 0 & 120 \\
\hline D & $\begin{array}{l}\text { What role(s) should the } \\
\text { government play? }\end{array}$ & Major 90 & NGOs 30 & 0 & 120 \\
\hline E & $\begin{array}{l}\text { What role(s) should the private } \\
\text { sectors play? }\end{array}$ & Less 15 & $\begin{array}{c}\text { NGOs \& } \\
\text { Govt. 105 }\end{array}$ & 0 & 120 \\
\hline F & $\begin{array}{l}\text { How should government ensure } \\
\text { laws? Pragmatic or democratic } \\
\text { process }\end{array}$ & $\begin{array}{c}\text { Pragmatic } \\
94\end{array}$ & $\begin{array}{c}\text { Democratic } \\
25\end{array}$ & 1 & 120 \\
\hline G & $\begin{array}{l}\text { Do you have confidence in } \\
\text { Government to effectively enact } \\
\text { and implement gender policies in } \\
\text { the country }\end{array}$ & Yes 55 & No 64 & 1 & 120 \\
\hline & & & & & $\mathbf{3 , 7 2 0}$ \\
\hline & Total Statements & & & \\
\hline
\end{tabular}

Derived from field Research 2012-2014

Table 9: Summary of Focus Group Respondents' Statements

\begin{tabular}{|l|l|l|l|l|}
\hline Zone & $\begin{array}{l}\text { No of } \\
\text { Statements }\end{array}$ & $\begin{array}{l}\text { Benefit } \\
\text { from } \\
\text { Govt. } \\
\text { Programs }\end{array}$ & $\begin{array}{l}\text { Benefit } \\
\text { from } \\
\text { NGOs } \\
\text { Program }\end{array}$ & $\begin{array}{l}\text { Total No of } \\
\text { Statements }\end{array}$ \\
\hline North-Central & & 200 & 450 & 650 \\
\hline North-East & & 175 & 255 & 430 \\
\hline North-West & & 133 & 267 & 400 \\
\hline South-South & & 247 & 553 & 800 \\
\hline South-West & & 211 & 449 & 660 \\
\hline South-East & 269 & 511 & 780 \\
\hline $\begin{array}{l}\text { Total Statement during the } \\
\text { focus group Discussion }\end{array}$ & $\mathbf{3 , 7 2 0}$ & \multicolumn{3}{|l}{} \\
\cline { 1 - 3 }
\end{tabular}

Derived from field Research 2012-2014

The following section provides a detailed discussion of the 3,720 statements made during the focus group discussions. The focus group discussion findings show the gaps in knowledge about gender consciousness and discrimination against women in Nigeria. The grid of statements and their relevant themes are presented in the tables 8 and 9.

This study finding is consistent with those of Ghana (Dibie and Atibil, 2012). However, the study has some refreshing revelations related to domestic abuse, sexual harassment, and lack of appropriate gender policies in Nigeria. The study provides a clear profile of the positive relationship between culture and religion and domestic abuse of women in 
Nigeria. It also reveals the positive relationship between government policies and its inability to enforce domestic abuse crime, sexual harassment, and male hostile domination. A revelation, which merits separate mention, is the religious and cultural competency of the focus group questions. The fact that the Community Advisory Board had to reframe the focus group questions in a number of instances shows a deficit in the ability of experts to speak at a level that is comfortable to these low-income women.

Respondents also acknowledge that domestic abuse, or spousal abuse, occurs when one person is an intimate relationship or marriage tries to dominate and control the other person. Domestic abuse that includes physical violence is called domestic violence. Domestic violence and abuse are used for one purpose and one purpose only: to gain and maintain total control over a woman in most cases, in some few cases men that are dominated by their wives. An abuser doesn't "play fair." Abusers use fear, guilt, shame, and intimidation to wear you down and keep you under his or her thumb. Your abuser may also threaten you, hurt you, or hurt those around you.

The participant in the focus group discussion indicated that domestic abuse often escalates from threats and verbal abuse to violence. And while physical injury may be the most obvious danger, the emotional and psychological consequences of domestic abuse are also severe. Emotionally abusive relationships can destroy a woman's self-worth, lead to anxiety and depression, and make her feel helpless and alone. No one should have to endure this kind of pain-and the first step to breaking free is recognizing that a woman's situation is abusive. Once a woman acknowledges the reality of the abusive situation, then she can plan to get the help she needs.

A counsellor and member of staff in one of the NGOs indicated that there are many signs of an abusive relationship. The most telling sign is fear of a woman's partner. If a wife feels like she has to walk on eggshells around her partner-constantly watching what she says and does in order to avoid a blow-up-chances are her relationship is unhealthy and abusive. Other signs that a woman may be in an abusive relationship include a partner who belittles her or tries to control her, and feelings of self-loathing, helplessness, and desperation. The focus group discussion ended by suggesting that if anyone suspects that someone they know is being abused, they should speak up. If they hesitating—stating that it's none of their business, they might be wrong, or the person might not want to talk about it-keep in mind that expressing your concern will let the person know that you care and may even save his or her life. 
The focus group discussion data support hypotheses 5 and 6 . The data shows that there is a positive relationship between culture and religion and domestic abuse of women in Nigeria. In addition, the focus group data shows a positive relationship between government policies and its inability to enforce domestic abuse crime, sexual harassment, and male hostile domination against women.

\section{Policy Recommendations}

Although more women are being employed in the agricultural and retail sectors in Nigeria, economic and cultural changes in the country are making it easier for women to become entrepreneurs. More women than before are leaving the home in increasing number to work in various sectors of the country. However, occupational segregation by gender, a situation in which men gets higher paying jobs than women continues to reinforce gender stereotype in Nigeria. Given the complexity of what needs to be done to empower women in Nigeria the public sector (governments), the private nonprofit sector (NGOs and civil society) and the private for-profit sector (businesses and corporations) have to engage one another in a productive partnership in that effort (Dibie, 2012). Each sector ought to bring to the table what they are best at - their comparative advantage. This is important because many NGOs have been led by the neo-liberal policies of their Western donors to think that Nigeria, because of its inadequacies, is irrelevant to the development process. In reality Nigeria has a vital role in development; sustainable development will not be possible or effective without women's active involvement. This section suggests ways in which the three sectors can do their part in a coordinated manner to better the lives of women in Nigeria.

The federal and state governments should clearly define their concept of development in consultation with civil society, relevant NGOs and the private for-profit sectors. Nigeria's Vision 2020 development plans should reflect a definition of development that assigns a central place to gender equality in all spheres of life - public and private, given the acknowledgement that sustainable development is dependent on harnessing the skills and energy of all citizens, including men and women.

There is the need for the enactment of NGOs legislation in Nigeria that outlines the relationship between the state and the nonprofit sector to create the framework for collaboration. Some states in Nigeria have also been trying to enact such legislations for many years but have met with resistance from the NGOs, which suspect state 
emasculation of civil society activities. The states on their part cite the need for weeding out fake NGOs, coordinating the activities of genuine NGOs and aligning them with the state's development plans. NGOs have to accept the fact that despite the neoliberal rhetoric of rolling back the state, they still have the responsibility for coordinating all activities within their borders, including private sector activities and ensuring the provision of public goods and services.

The federal and state governments of Nigeria have to commit to making gender equality and women's empowerment a priority, beyond the creation of women's ministries and nominal gender mainstreaming. The federal and state governments have a duty to provide the needed infrastructure and create incentives for the private nonprofit sector to deliver programs that enhance women's lives in the following major areas: (1) education; (2) economic participation; (3) environmental conservation; (4) health; (5) political participation; and (6) social and cultural change.

The study recommends that women empowerment could be achieved through social and economic intervention. This intervention involves improved competence, self-reliance and self- esteem. If women are able to successfully achieve competence, self-reliance and self-esteem they could be in a better position to attain improved mental health as well as improved physical health. In addition, the politics of disengagement could help women to manipulate the formal or alternative sources of power to achieve equal rights as their male counterpart in the country.

Education also reduces the desire for more children and checks population growth. Meanwhile research shows that tertiary education, not elementary education, is what provides the greatest benefit to women (Tagoe, 1999). With the huge gaps between men and women in the area of educational attainment in Nigeria, especially at the secondary and tertiary levels, the government needs to not just step up programs to increase girls' enrolment in elementary schools but also their retention in school to ensure that the majority of them attain at least secondary education. NGOs should focus on education (adult literacy, children's and especially women's education) could be encouraged through enhanced tax deductions and tax credits for donations made to these NGOs. The federal and state governments ought to look into encouraging corporate social responsibility. Private companies operating in Nigeria should be given special incentives to contribute towards the education of girls and women in public as well as private schools. 
Government and NGOs Performance with Respect to Women Empowerment in Nigeria 127

Table 10: Policies for Women's Empowerment

\begin{tabular}{ll}
\hline Policy Variable & Description
\end{tabular}

1. Equal Credit Opportunity Policy: To prohibits discrimination in credit on the basis of sex or marital status.

2. Pregnancy Discrimination Policy: To prohibit discrimination on the basis of pregnancy, childbirth, or related medical conditions.

3. Civil Rights Policy: To provide monetary damages in cases of intentional employment discrimination against women all over the country.

4. Equal Employment Opportunities: Equal opportunity and other ethnic-conscious instruments designed to benefit the marginalized girls and middle age women.

5. Law against Women Abuse: Take action to prosecute men who engage in domestic violence or physically abuse their wives.

6. National Sexual Harassment Policy: Prosecute men especially senior administrators who use their position in the workplace to intimidate junior female employees or demand sex as a condition for continuous employment or promotion.

7. Law against Gender Discrimination: Take action to stop gender discrimination in the hiring and promotion process.

8. Inter State Succession Law or Law of Divorce: Enact divorce laws that will grant wives right to equitable share property with their ex-husband as well custody rights of children from the marriage.

9. Public Education Campaign to change: Introduce civil society campaign to educate traditional, social, cultural, and religions rural and urban communities that the time is right stereotype on women for the nation to change some of its outdated values about girls and women.

10. Pay Equity Policy: Equal pay for equal work and qualification. Public policy to reverse pay inequality in favour of women and men. 
11. Alternative Work Patterns for Women: Introduce policy that could allow women to be innovative in work patterns as flexi-time, staggered hours, compact work week, job sharing, and flexi-year.

12. Child Day Care Assistance: Public and private institutions should be encouraged to provide child day care facilities around their location.

13. Women Participation in Politics: Create an environment that will encourage women to participate in politics and occupy key positions in political parties.

14. Diversity in Women Education: (a) Girls and middle age women should be encouraged to complete at least a high school diploma. (b) Women should be encouraged to be Scientists, Engineers, Pilots, Computer Experts and Doctors

15. Law on Women Control over their reproductive decision: Establish laws to ensure sexual equality, and guarantee women's control over their own reproductive decisions.

16. Women Co-operative Societies and NGOs: Encourage the consolidation of women's economic power through co-operative societies and NGOs around the nation.

Source: Dibie, R. (2009). "Globalization and Women Empowerment in Africa" in Globalization and Third World Women, Ligaya Lindio-McGovern and Isidor Wallimann, edited. Adershort, England: Ashgate

\section{Conclusion}

This paper has examined the role of NGOs and government in the empowerment of women in Nigeria. It argues that equal respect and opportunities must be given to women and men in the sustainable development and capacity building processes in Nigeria. In addition, economic development in Nigeria requires increasing educational opportunities and accomplishment of women in the country. Such policy could provide greater utility, self-confidence and greater sense of empowerment, declining fertility rates and other forces of modernization that could contribute to the growth of the number of women in the workforce. Efforts by the government of Nigeria to provide more access of financial support for women could promote economic development. NGOs seem to be doing more in the empowerment women in the Nigeria than the government. The study finding shows that most NGOs are unaccountable to the government or other 
Government and NGOs Performance with Respect to Women Empowerment in Nigeria 129

institutions in Nigeria. It is also difficult to assess their real impact since many NGOs do not properly evaluate their outcomes. In Nigeria the fact that NGOs insist on their autonomy from the government creates problems with national macro-economic development planning and coordination. This is because NGOs do not coordinate their activities with the appropriate government ministries. This has resulted in uneven programmers and services among the various states in the country as well as the overlap of services among NGOs.

An important significance of the research is that NGOs working on women's advancement in Nigeria are forced to limit themselves to the provision of social services such as health, education, micro-enterprises, and domestic abuse as opposed to advocating for fundamental policy and legal changes. This is because bilateral and multilateral donors claim political neutrality and label advocacy as a political activity.

This study also provides evidence on the nature of NGOs women empowerment programmers in Nigeria. It also provides more evidence on the relationship between NGOs and women empowerment in Nigeria. In addition the study adds to the body of literature and knowledge on women empowerment in the country. It provides current information for the formulation of future public policy on gender and how to reverse the discrimination against women in Nigeria. The study also addressed the complex ways on how to effectively mobilize women to equally contribute to the sustainable development processes in Nigeria.

There is reason to be cautious about what NGOs have accomplished in the empowerment of women in Nigeria and their future role in this endeavour. It is, therefore very important to observe that good intentions should not be equated with outcomes. Indeed, some critics in Nigeria believe that NGOs have become avenues for enterprising individuals and some government officials to take advantage of funding from abroad for their personal, rather than the common good (Dibie and Atibil, 2012). As one scholar put it, "the fact that the institutions [of state] are not able to make NGOs accountable is itself problematic (Bolaji 2006; OECD 2010).

NGOs in Nigeria tend to operate more like private businesses that seek foreign aid for purposes of personal enrichment (Lehne, 2013). To be more effective, it would be important for NGOs, the federal and state governments of Nigeria to collaborate in a more constructive and professional manner, on various levels; in order to ensure gender equality as well as equitable and sustainable development goals. The socio-economic 
and political problems faced by Nigerian women are closely associated with gender inequality. These problems are too complex to be tackled by any one sector on its own because of cultural and religious values in the country. However, appropriate gender equality policies could help to resolve this major predicament in the sustainable development goals of Nigeria.

\section{List of References}

- Acholonu, C. (1995). Motherism: The Afrocentric Alternative to Feminism LHHP Women in Environment Development Series, 3

- Adeleke V. I. (2004). Concept of Gender Equality: As a Paradox in Nigeria's Democratic Experience. Babcock University: Department of Political Science and Sociology, Monograph Series, No.1, 1-24.

- Adeleke, V. (2002). "Nigerian Women and National Development". Babcock Journal of Management and Social Sciences, vol. 1 no. 1 pp.73-89.

- African Women's Development Fund (AWDF) (2009). Annual Report 2007-2008. ANNUAL_REPORT_2007-2008_.pdf [accessed December 28, 2010]

- Ako-Nai, R. (2013). Gender and Power Relations in Nigeria. Lanham, M.D.: Lexington Books

- $\quad$ Alexander, A. and Welzel, C. (2007). "Empowering Women: The Role of NGOs'. www.democ.uni.edu/.../DD08/Alexander.doc. Accessed 15/06/2011

- Amali, E. (2000). "Gendered Economics and Women's Inclusion in Economic Politics in a Democratic Era: A Nigerian Perspective" in Oyin Ogunba (ed.) The Empowerment of the Civil Society in a Democracy: Nigeria and the United States of America. Ile-Ife: American Studies Association

- Angya C. (2005) Perspectives on Violence against Women in Nigeria. Aboki Publisher, Abuja.

- Anheier, H. and Lester S. (2006). "The Nonprofit Sector in Comparative Perspective." in The Nonprofit Sector: A Research Handbook. 2nd ed. Walter W. Powell and Richard Steinberg (eds). New Haven \& London: Yale University Press 
- Annual Reports (2009): Agents of Change International Women's Development Agency

- Attoe, S. (2002). "Women in the Development of Nigeria since Pre-colonial Times". www.onlineNigeria.com , Community Portal of Nigeria Accessed October 2, 2011

- Batliwala, S. and Deepa D. (2007). "Gender Myths That Instrumentalize Women: A Viewed from the Indian Front line." Feminisms in Development: Contradictions, Contestations and Challenges. Andrea Cornwall et al (eds). London: Zed Books, pp. 21-34

- Bolaji, K. (ed) (2006). Towards Greater Participation of Nigerian Women in Democratic Governance and Development: Challenges and Prospects

- Chandaria, A. (2006) Women's Empowerment Through Group Economic and Educative Activities 137-143. koed.hu/sw249/shit.pdf Accessed January 12, 2015.

- Cloete F. and Christo d. (2011). Improving Public Policy. Pretoria: South Africa: Van Schalk Press.

- Coleman, I. (2004). "The Payoff from Women's Rights." Foreign Affairs. 83 (3): 80-95.

- Conway, M.t. Steuernagel, G. and Ahern, D. (2010). Women and Political Participation in Third World. Washington, DC: CQ Press.

- Dibie J. and Dibie, R. (2012). "Non-Governmental Organizations (NGOs) and the Empowerment of Women in Africa." African and Asian Studies Journal, Vol. 11, no. 1, 95-122.

- Dibie, R, and Atibil C. (2012). "NGOs and Women Empowerment in Ghana and Nigeria." Journal of International Politics and Development Vol. 12, 1\&2, pp. 25-44.

- Dibie, R. (2009). "Globalization and Women Empowerment in Africa" in Globalization and Third World Women, Ligaya Lindio-McGovern and Isidor Wallimann, edited. Adershort, England: Ashgate

- Dibie, R. and Offiong, O. (2009). Gender Egalitarianism and Public Service in Nigeria. Journal of International Politics and Development Vol. 7, No. 2, pp.21-50

- Dibie, R. and Dibie, J. (2008), "Current and Future Roles of NGOs in the Empowerment of Women in Africa". In Non-Governmental Organizations (NGOs) and Sustainable Development in Sub-Sahara Africa. R. Dibie (ed.) Lanham: Lexington Books pp.229-251

- Dibie, R. (2008). "Introduction: NGOs and Human Development in Africa: Theory and Model for Collaboration" In Non-Governmental Organizations (NGOs) and Sustainable Development in Sub-Saharan Africa, Robert A. Dibie (Ed). Lanham: Lexington Books, pp.125 
- Dichter, T. (1999). "Globalization and Its Effects on NGOs: Efflorescence or a Blurring of Roles and Relevance?" Nonprofit and Voluntary Sector Quarterly, Supplement 28 (4):38-58.

- Ezeilo, J. (2006). "Feminism and Islamic Fundamentalism: Some Perspectives from Nigeria and Beyond." SIGNS: Journal of Women in Culture and Society. 32 (1):F.A.O. http://www.fao.org/docrep /x0250e/ x0250e03 .htm [accessed December 12, 2010]

- $\quad$ Fallon, K. (2003). "Transforming Women's Citizenship Rights within an Emerging Democratic State: The Case of Ghana". Gender \& Society 17 (4): 525-543

- Federal Ministry of Justice (2008). Nigeria's 3rd Periodic Country Report: 2005-2008 On the Implementation of the African Charter on Human and People's Rights in Nigeria. Abuja: Federal Ministry of Justice

- Ferguson, A. \& Hennessy, R. (2010). Feminist Perspectives on Class and Work. Stanford Encyclopedia of Philosophy.

- Ferrell, O., Fraedrich J., and Ferrell, L. (2015). Business Ethics: Ethical Decision Making and Cases. Mason, $\mathrm{OH}$ : South-Western.

- $\quad$ Ferris E. (2005) "Faith-based and Secular Humanitarian Organizations" International Review of the Red Cross, Volume 87 Number 858

- Fonjong, L. (2001) "Fostering Women's Participation in Development through nongovernmental efforts in Cameroon", Geographical Journal, Vol. 167, No.3, pp 223 - 23

- Green, D. (1999). Gender Violence in Africa. New York, NY: St. Martin's Press.

- Hausmann, R. et al. (2010). "The Global Gender Gap Index 2010: Measuring the Global Gender Gap." In The Global Gender Gap Report 2010. Hausmann, Ricardo et al. eds. World Economic Forum: Geneva

- Hausmann, R. et al. (2006). The Global Gender Gap Report 2006. World Economic Forum: Geneva

- Hosmer, L. (2006). The Ethics of Management. Boston, MA: McGraw Hill Press.

- Hudson-Weems, C. (1997) "African Womanism and the Critical Need for African Theory and Thought", Journal of Black Studies, 212:2, pp79-84

- Inglehart, R., Norris P., and Welzel, C. (2002). "Gender Equality and Democracy." Comparative Sociology 1: 321-345.

- Inglehart, R., Norris P., and Welzel, C. (2005).Modernization, Cultural Change and Democracy: The Human Development Sequence. Cambridge University Press 
- Islam, N. and Sultana,N. (2005) "Role of NGOs in Empowering the Vulnerable Women: A Case Study on ACD" Asian Affairs Vol. 27 No 4: 24-4/

- Kalu, A. (1996). "Women and the Social Construction of Gender in African Development." Africa Today. 43 (3): 269-288. Scientific Study of Population pp. 73-97

- Kant, I. (1797 \&1999). Metaphysical Elements of Justice, second ed, John Ladd trans. Indianapolis, IN: Hackett Press

- Lehne R. (2013). Government and Business. Washington D. C.: Congressional Quarterly Press and Sage.

- Locke, J. (1960 \&1689). The Second Treatise of Government in Two Treatises of Government, Peter Laslett, ed. Cambridge, MA: Cambridge University Press: 283-446.

- Mings, K. A. (2004). Essentials of International Relations. New York: W.W. Norton and Company.

- Moellendorf, D. (2002). Cosmopolitan Justice. Boulder, CO: Westview Press.

- Makinwa, K. and j. An-Magritt. (1995) Women's position and demographic change in Sub-Saharan Africa. Liège, Belgium : International Union for the Scientific Study of Population

- Mohmond, F. A. (2004). Are Human Rights Universal? Issues of Gender and Culture. African News.

- Nagar, R. 1. (2000) Women, NGOs and Contradictions of Empowerment and Disempowerment: A conversion

- National Economic Empowerment and Development Strategies (NEEDS). (2005).Abuja: National Planning Commission, Nigeria

- Nigeria Demographic and Health Survey (2008). dhsprogram.com /pubs /pdf/ SR173/ SR173.pdf. Accessed November 7, 2014.

- Nikkah, H. and Redzuan, M. (2010). "Issues in Women's Political Empowerment in the AsiaPacific Region" Kamla-Raj J. Hum Eco1 30(2) pp.85-92.

- Nickel, J. W. (2000). "Economic Liberties," in V. Davion and Clark Wolf, eds., The Idea of a Political Liberalism: Essays on Raw/s, New York: Rowman and Littlefield.

- Nozick, R. (1974). Anarchy, State, and Utopia. New York: Basic Books.

- Nussbaum, M. (1999). Sex and Social Justice. New York: Oxford University Press. 
- Nussbaum, M. (2000). Women and Human Development. Cambridge, MA: Cambridge University Press.

- Oakley, P. Bortei-Doker, E. Therkilden, O. Sanders, D. Harland, C. Hobley, M. and Garibay, A. H. (1991). Projects with People: The Practice of Participation in Rural Development. Geneva: International Labour Office.

- Odumosu O. et al (2009). "Mapping the Activities of Faith-based Organizations in Development in Nigeria." Birmingham: Religions and Development Working Paper 38

- Organization for Economic Co-operation and Development (OECD) report in (2010). Nigeria, in Atlas of Gender and Development. Hhtp://dx.doi.org/10.1787/9789264077478124-en. Accessed November 7, 2014.

- Organization for Economic Co-operation and Development (OECD) report in (2008). www.investopedia.com/terms/o/oecd.asp. Accessed November 7, 2014.

- Ogidefa, I. (2008). "Women and Politics in Nigeria." Retrieved on March 15, 2010 from http. //beyondJane.com/women and politics in Nigeria.

- Ojobo, J. (2008) "Education: A Catalyst for Empowerment in Nigeria", Ethiopian Journal of Education and Science Vol. 4 No. 1

- Okojie, C.E.E. 1995. "The Relationship between Women's Status, Proximate Determinants and Fertility in Nigeria." In Women's Position and Demographic Change in Sub-Saharan Africa.

- Okpe O. and Angya, C. (2007). Women and Faith-Based Organizations in Nigeria. Benue State University Centre for Gender Studies, Monograph Series No. 1-37.

- Oyewumi, O. (2002). "Conceptualizing Gender: The Eurocentric Foundation of Feminist Concepts and the Challenge of African Epistemologies." http://www.codesria.org/IMG/pdf/OYEWUMI.pdf. Accessed June 10, 2011.

- Phillips, L. (2006). The Womanist Reader. New York: Routledge Press.

- Rawls, J. (2001). Justice as Fairness: A Restatement. Cambridge: Harvard University Press.

- Rawls, J. (1996). Political Liberalism, New York: Columbia University Press.

- Rawls, J. (1971). A Theory of Justice. Cambridge: Harvard University Press.

- Reiman, J. (1990). Justice and Modern Moral Philosophy. New Haven, CT: Yale University Press. 
Government and NGOs Performance with Respect to Women Empowerment in Nigeria 135

- Roumberoutsos, A. B. (2010). Sustainability, Social Discount Rates, and the Selection of Project Procurement Methods. International Advances in Economic Research, Vol. 16, 165174.

- Sen, A. (1997). "Maximization and the Act of Choice." Econometrica 65(4):745-779.

- Sen, A. (2009). The Idea of Justice. Cambridge: Harvard University Press.

- Sha, P. (2007) Globalization and Challenges of organizing among Women in the Informal Sector in Nigeria. Benue State University Centre for Gender Studies, Monograph Series no. 2, 2007.

- Schirch, L. (2012) "Understanding Women as victims and Peace-builder." In Schnabel, A. and A. Tabyshalieva edited, Defying Victimhood: Women and Post=Conflict PeaceBuilding. New York: United Nations University Press.

- $\quad$ Scott C. (2009). Gender, Faith-based, and Development in West Africa. London: Lynne Rienner Publisher.

- $\quad$ Smee, S. \& Woodroffe, J. (2013). Achieving Gender Equality Through a Post-2015 Framework. Institute of Development Studies Policy Brief Issue 43, (August), pp. 1-2.

- The Constitution of the Federal Republic of Nigeria. (1999), cited in Dibie, R. (2014). Public Administration: Theory, Analysis, and Application. Ilishan-Remo: Nigeria. Babcock University Press.

- Theron, F. (2008). The Development Change Agent. Pretoria, South Africa: Van Schaik Press

- Turner, M. and Hulme, D. (2006). "NGOs and Their Role in the Global South" International Journal of Not-for Profit Law Vol. 9 No 1, p. 26.

- Umeha, C. (2010). "Women: The Journey to Political Relevance." Sunday Champion online. Retrieved on March 15, 2010 from http.// www.champion.comng/index pup category

- Usua A. and Osuagwu E. (2010). Women and Politics in Male-Dominated Sphere: Getting the Wolves and the Sheep to lie together through Media Advocacy" in G. Okon and A. Udoudo (eds.) Political Communication and Nigerian Democracy: A Book of Reading. Port Harcourt: Amethyst and Colleagues Publishers pp.123-132

- Vaquez, P. (1996). Classics of International Relations. Upper Saddle River, N.J.: Prentice Hall Press.

- Vogel, L. (2013). Marxism and the Oppression of Women: Toward a Unitary Theory. PA Leiden, The Netherlands: Brill Press. 
- Walker, A. (2003). In Search of Our Mother's Garden's: Womanist Prose. Orlando, FL: Harcourt Books

- Waylen, G (2006). Gender in Third World Politics. . London: Lynne Rienner Publisher.

- Waylen, G. (1996). Gender in Third World Politics. Boulder, Co: Lynne Rienner Publishing Company.

- World Bank. World Development Report. (2005). New York: Oxford University Press.

- World Bank. World Development Report. (2013). New York: Oxford University Press.

\section{AUTHORS' CONTACT:}

\section{DIBIE Robert | OKERE Justina Sam}

School of Public and Dept of Political Science and Public

Environmental Affairs Administration

Indiana University

Kokomo, USA

Babcock University

Ilishan-Remo, Nigeria

Email: rdibie@yahoo.com

Email: tinasamokere@yahoo.com 